\title{
ACTIVITY OF THE MITOCHONDRIAL ISOENZYMES OF ENDOGENOUS ALDEHYDES CATABOLISM UNDER THE CONDITIONS OF ACETAMINOPHEN-INDUCED HEPATITIS
}

\author{
O. M. VOLOSHCHUK, G. P. KOPYLCHUK, Y. I. MISHYNA
}

\author{
Yuriy Fedkovych Chernivtsi National University, \\ Institute of Biology, Chemistry and Natural Resources, Ukraine; \\ e-mail: o.voloschuk@chnu.edu.ua
}

\begin{abstract}
The research deals with the determination of the activity of aldehyde dehydrogenase (EC 1.2.1.3), aldehyde reductase (EC 1.1.1.21) as well as the content of TBA reactive substances and protein carbonyl derivates in the rat liver cytosolic fraction under the conditions of acetaminophen-induced hepatitis and protein deficiency. The most pronounced decrease in the activity of enzymes utilizing endogenous aldehydes is observed in the liver cytosolic fraction of animals with toxic liver injury maintained under the conditions of alimentary protein deficiency. Meanwhile, the accumulation of TBA reactive substances and protein carbonyl-derivates in the liver cytosolic fraction of animals of this experimental group was established. The accumulation of aldehyde products of lipid and protein oxidative damage on the background of the reduction in the activity of enzymes providing aldehyde catabolism may be considered as a possible mechanism underlying hepatocyte dysfunction under the conditions of toxic damage in protein-deficient animals.
\end{abstract}

Key word s: aldehyde dehydrogenase, aldehyde reductase, TBA reactive substances, protein carbonyl derivatives, alimentary protein deficiency, hepatotoxicity, mitochondria.

$\mathrm{T}$ oday it is known that mitochondrion is the key metabolic center of the cell [1], because it carries out a number of important biological functions: provides the oxidative phosphorylation and $\beta$-oxidation of fatty acids, participates in the maintaining of the cell calcium homeostasis, biosynthesis of lipids, heme, iron-sulfur clusters and some amino acids, etc. [2, 3]. However, mitochondria are considered as the main source of reactive oxygen species which can influence intracellular signaling, regulation of cell functions and non-specific immune response $[4,5]$. Nevertheless, due to their high oxidation potential, the reactive oxygen species are capable of damaging cell structure and inducing a number of chain reactions leading to the uncoupling of integration functions in the organism [6]. Increased generation of reactive oxygen species causes the formation and accumulation of carbonyl products, among which aldehydes demonstrate the most pronounced cytotoxic and genotoxic properties.
Endogenous aldehydes act as the original messengers of cell damage during oxidative stress [7]. Therefore, there is an aldehyde dehydrogenase pathway of endogenous aldehydes catabolism, which function is the oxidation of aldehydes to carboxylic acids, and aldehyde reductase pathway that catalyzes the reduction of endogenous aldehydes to alcohols [7, 8]. Neutralization of carbonyl metabolites is considered as a mechanism of protecting cells from alteration under the different pathological conditions involving oxidative stress. Our previous research showed the pronounced intensification of free radical processes in the liver mitochondrial fraction under the toxic liver injury on the background of alimentary protein deficiency [9].

Therefore, the aim of the current work was to determine the activity of aldehyde dehydrogenase (EC 1.2.1.3), aldehyde reductase (EC 1.1.1.21), the content of TBA reactive substances and protein carbonyl derivatives in the rat liver mitochondrial frac-

(C) 2018 Voloshchuk O. M. et al. This is an open-access article distributed under the terms of the Creative Commons Attribution License, which permits unrestricted use, distribution, and reproduction in any medium, provided the original author and source are credited. 
tion under the conditions of acetaminophen-induced hepatitis on the background of dietary protein deprivation.

\section{Materials and Methods}

The experiments were conducted on 36 white rats of 90-100 g body mass aged 2-2.5 months. The experiment was conducted in accordance with the rules set by the European Convention for the Protection of Vertebrate Animals Used for Experimental and Other Scientific Purposes (Strasbourg, 1986).

The animals were separated into solitary plastic cages with sand bedding and ad libitum access to water.

The daily rations were regulated according to principles of pair feeding. The animals were divided into the following experimental groups: I - animals receiving full-value semi-synthetic ration (C); II animals receiving low-protein ration (LPR); III animals with acetaminophen-induced liver injury receiving complete ration $(\mathrm{H})$; IV - animals with acetaminophen-induced liver injury that were previously maintained on semi-synthetic low-protein ration $(\mathrm{LPR}+\mathrm{H})$.

The animals of the groups I and III received a standard ration containing 14\% of protein (casein), $10 \%$ of fat, and $76 \%$ of carbohydrates, balanced by all the essential nutrients. The animals of the groups II and IV received isoenergetic ration containing $4.7 \%$ of protein, $10 \%$ of fat, and $85.3 \%$ of carbohydrates, calculated after recommendations of the American Institute of Nutrition [10].

The animals were maintained on the corresponding diet during four weeks. Afterwards, the acetaminophen-induced liver injury was modeled by per os administration of $2 \%$ starch suspension of acetaminophen in daily dose $1 \mathrm{~g} / \mathrm{kg}$ of the body weight during 2 days [11].

Cervical dislocation was performed under the light ether anesthesia on day 31 of the experiment.

Mitochondrial fraction of the liver homogenate was separated by differential centrifugation (Heraeus Biofuge, Germany) in the following buffer medium: $250 \mathrm{mM}$ sucrose, $1 \mathrm{mM}$ EDTA, $10 \mathrm{mM}$ Tris-HCl; $\mathrm{pH} 7.4$ at $0-3{ }^{\circ} \mathrm{C}$.

Enzyme assays. Aldehyde dehydrogenase activity was determined spectrophotometrically (Agilent Technologies, USA). The reaction mixture contained: $50 \mathrm{mM}$ sodium pyrophosphate buffer (pH 8.8), $1 \mathrm{mM}$ acetaldehyde, $1 \mu \mathrm{M}$ rotenone, $50 \mu \mathrm{M}$ $\mathrm{NAD}^{+}$and $500 \mu \mathrm{g}$ protein of mitochondrial fraction in a total volume of $3 \mathrm{ml}$. Enzymatic activity was calculated using the molar extinction coefficient of $\mathrm{NAD}^{+}$at a wave-length of $340 \mathrm{~nm}$ [12]. The enzyme activity was expressed in $\mathrm{nmol} \mathrm{NAD} / \mathrm{min}^{+} \mathrm{mg}^{-1}$ of protein.

Aldehyde reductase activity was determined spectrophotometrically (Agilent Technologies, USA). The reaction mixture contained $50 \mathrm{mM}$ potassium phosphate buffer ( $\mathrm{pH}$ 6.0), $10 \mathrm{mM}$ propionaldehyde, $0.1 \mathrm{mM}$ NADH and $500 \mu \mathrm{g}$ of protein of mitochondrial fraction. Aldehyde reductase activity was calculated using molar extinction of NADH at a wave-length of $340 \mathrm{~nm}$. The enzyme activity was expressed in nmol NADH/min'mg ${ }^{-1}$ of protein [13].

TBA reactive substances assay. The concentration of TBA reactive substances was assessed by the reaction with 2-thiobarbituric acid (TBA), occurring at high temperature in acidic environment, and forming the colored complex, determined spectrophotometrically (Agilent Technologies, USA) at $\lambda 532 \mathrm{~nm}\left(\varepsilon=1.56 \cdot 10^{5} \mathrm{M}^{-1} \cdot \mathrm{cm}^{-1}\right)$ [14]. The concentration of TBA-active products was expressed in $\mathrm{nmol} /$ mg of protein.

Protein carbonyl derivatives content assay. Protein carbonylation was assessed via amount of 2.4-dinitrophenylhydrazone derivatives, produced in reactions of oxidized amino acid residues with 2.4-dinitrophenylhydrazine, and expressed as nmol of carbonyl protein derivatives per mg of protein [15].

Protein determination. The protein content was determined according to the method of Lowry et al [16].

Data analysis and statistics. The data were compared and analyzed by using unpaired $T$-test. Characteristics of the study group were expressed as mean \pm SD for normal distribution. For all statistical calculations, the significance was considered to be a value of $P<0.05$.

\section{Results and Discussion}

The results of the study have shown that the enzymatic activity of aldehyde dehydrogenase, which catalyzes the oxidation reaction of aldehydes to carboxylic acids [17], was decreased in the liver mitochondrial fraction of all experimental groups of animals (Fig. 1). But the most pronounced change in the enzymatic activity was detected in the liver mitochondrial fraction of animals with toxic liver injury maintained under the conditions of dietary protein deprivation. The mitochondrial aldehyde 
dehydrogenase activity was decreased more than 2 times in animals of this group (Fig. 1).

Meanwhile, we observed the decreased activity of mitochondrial isoform of aldehyde reductase, which catalyzes the reduction of aldehydes to alcohols [8] in the animal liver mitochondrial fraction of all experimental groups (Fig. 2). Our study has established the maximal lowering of aldehyde reductase reaction in protein-deficient rats with liver toxicity.

On the one hand, the reduction in the catalytic activity of studied enzymes can be probably associated with its inhibition by reactive polar metabolite of acetaminophen - N-acetyl-p-benzoquinone imine which is produced by cytochrome $\mathrm{P} 450$ isoenzymes. Today the formation of covalent complexes of acetaminophen metabolites with mitochondrial enzymes

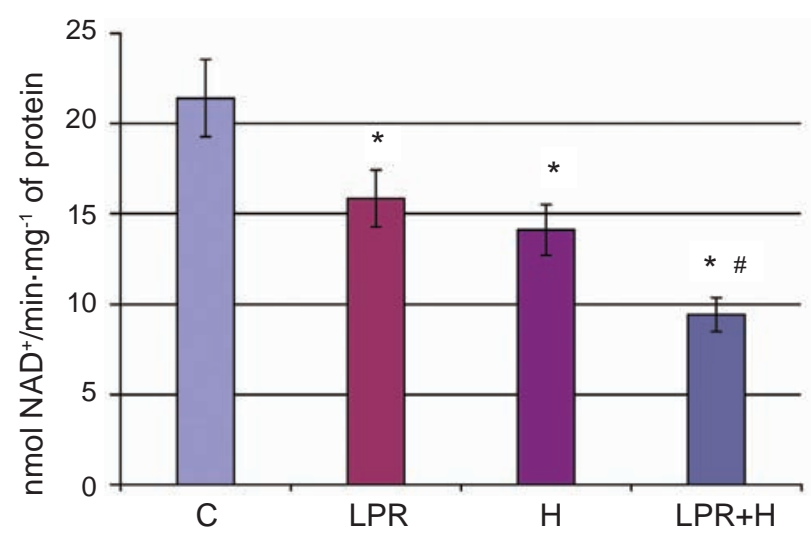

Fig. 1. The enzymatic activity of aldehyde dehydrogenase in the rat liver mitochondrial fraction under the conditions of acetaminophen-induced hepatitis and alimentary protein deprivation. The data are presented as mean $\pm S D$ for normal distribution, $n=9$. $C$ bar shows the value of parameter in the liver of control group of rats maintained on the balanced diet; LPR bar shows the value parameter in the liver of rats receiving low-protein ration (LPR); $H$ bar shows the value of parameter in the liver of rats with acute acetaminophen-induced hepatitis, maintained on the balanced diet; $L P R+H$ bar shows the value of parameter in the liver of rats with acute acetaminophen-induced hepatitis that were previously maintained on semi-synthetic low-protein ration $(L P R+H)$. Here and in Fig. 2-4: *Significantly different from the control (C) group. "Significantly different from the group with acetaminophen-induced hepatitis. $P \leq 0.05$ represents statistical significance

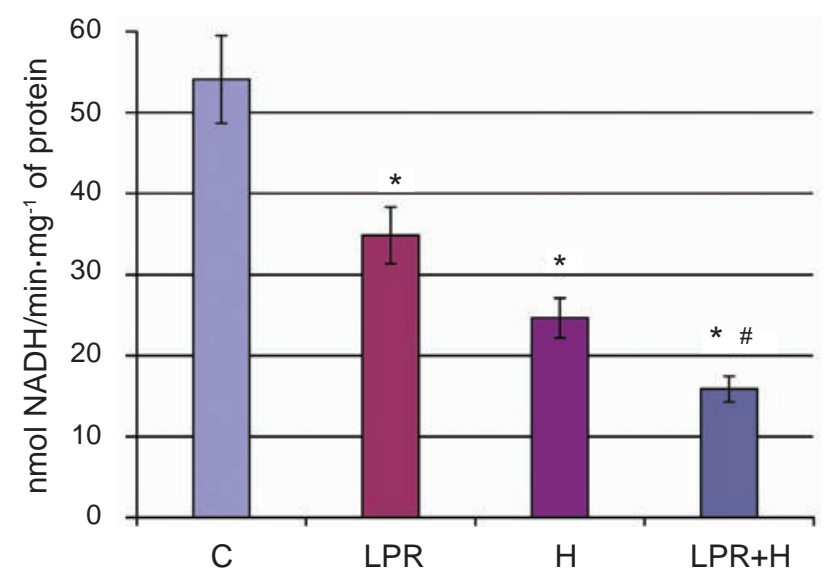

Fig. 2. The enzymatic activity of aldehyde reductase in the rat liver mitochondrial fraction under the conditions of acetaminophen-induced hepatitis and alimentary protein deprivation

is considered as a primary trigger of mitochondrial dysfunction after the exposure of toxic acetaminophen doses [18]. Furthermore, the disruption of the enzymes subunits synthesis may be observed under the conditions of protein deficiency.

Since aldehyde dehydrogenase and aldehyde reductase are key enzymes of endogenous aldehydes utilization, the reduction in their activity causes the accumulation of aldehyde adducts with cellular macromolecules. For this reason a determination of TBA reactive substances and protein carbonyl derivatives allows analyzing the intensity of toxic endogenous aldehydes accumulation in the cell [19]. It is known that oxidative stress causes formation of numerous aldehydes: saturated (ethanal, propanal, hexanal), unsaturated (acrolein, 4-hydroxy-2-nonenal and 4-hydroxy-2-hexenal) and dicarbonyls (glyoxal, methylglyoxal, malonic dialdehyde) through the polyol pathway of fatty acid peroxidation [7, 19]. These reactive carbonyl compounds are capable of non-enzymatic interaction with protein molecules, forming the irreversibly modified end products of lypoxigenation [20].

It is also known that aldehyde dehydrogenase is involved in the utilization of endogenous aldehydes, which are mostly products of lipid peroxidation and are defined as the thiobarbituric acid reactive substances [21]. In particular, aldehyde dehydrogenase metabolizes malondialdehyde to malonic acid through the stage of semialdehyde - the intermediate of this reaction. Further the decarboxylation of malonic acid leads to formation of acetyl-CoA that is involved in the citric acid cycle. Semialdehyde 


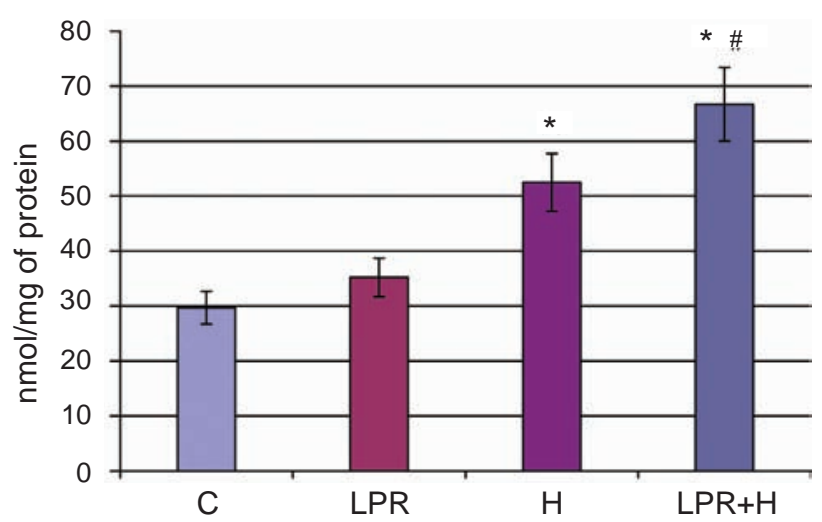

Fig. 3. TBA reactive substances content in the rat liver mitochondrial fraction under the conditions of acetaminophen-induced hepatitis and alimentary protein deprivation

of malonic acid can also be involved in the decarboxylation reaction with formation of acetaldehyde, which is oxidized by aldehyde dehydrogenase to acetate, from which acetyl-CoA is formed. Other endogenous aldehydes metabolize in similar way [17]. In turn, aldehyde reductase is involved in the reduction of mostly unsaturated endogenous aldehydes, which can play the main role in oxidative protein modification [22].

The results of this study suggest that the most intensive accumulation of TBA reactive substances and protein carbonyl-derivatives was observed in the liver mitochondrial fraction of rats with acetaminophen-induced hepatitis, which were subjected to dietary protein deprivation (Fig. 3, 4).

Intensive accumulation of TBA reactive substances can lead to the increase of viscosity and permeability of cell membranes, disturbances of their integrity, that causes an imbalance in the mechanisms of cellular homeostasis regulation [10, 17]. On the other hand, as the result of protein carbonyl derivatives accumulation in the mitochondria may be the fragmentation and denaturation of mitochondrial proteins with the subsequent interruption of mitochondrial pathways and membrane transport systems [19].

In conclusion, the accumulation of aldehyde products of lipid and protein oxidative damage in the mitochondrial fraction against the background of a decrease in the activity of enzymes providing aldehyde catabolism may be considered as a possible mechanism underlying the liver mitochondrial dysfunction under the conditions of toxic liver injury in protein-deficiency animals.

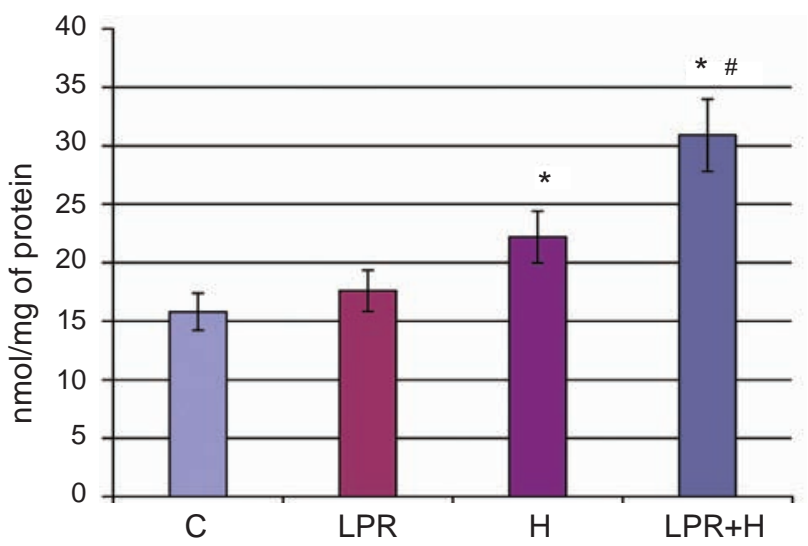

Fig. 4. Protein carbonyl derivatives content in the rat liver mitochondrial fraction under the conditions of acetaminophen-induced hepatitis and alimentary protein deprivation

\section{АКТИВНІСТЬ МІТОХОНДРІАЛЬНИХ ЕНЗИМІВ КАТАБОЛІЗМУ ЕНДОГЕННИХ АЛЬДЕГІДІВ ЗА УМОВ АЦЕТАМІНОФЕНІНДУКОВАНОЇ ГЕПАТОТОКСИЧНОСТІ}

\author{
О. М. Волощук, Г. П. Копильчук, \\ Ю. І. Мішина
}
Чернівецький національний університет імені Юрія Федьковича,
Інститут біології, хімії та біоресурсів; e-mail: o.voloschuk@chnu.edu.ua

У роботі вивчали активність альдегіддегідрогенази (КФ 1.2.1.3), альдегідредуктази (КФ 1.1.1.21), вміст ТБК-активних продуктів і карбонільних похідних протеїнів у мітохондріальній фракції печінки щурів за умов ацетамінофеніндукованого гепатиту та аліментарної депривації протеїну. Встановлено, що найвираженіше зниження активності досліджуваних ензимів спостерігалося в мітохондріальній фракції печінки щурів із токсичним ураженням, які утримувалися в умовах дефіциту харчового протеїну. Водночас у мітохондріях печінки тварин цієї групи встановлено накопичення ТБК-активних продуктів та протеїнових карбоніл-дериватів. Висловлюється припущення, що накопичення альдегідних продуктів окислювального пошкодження ліпідів та протеїнів на фоні зниження активності ензимів, які забезпечують їх катаболізм, 
може бути основою одного 3 механізмів мітохондріальної дисфункції в умовах токсичного ураження печінки за аліментарної депривації протеїну.

К л ю ч о в і с л о в а: альдегіддегідрогеназа, альдегідредуктаза, ТБК-активні продукти, карбонільні похідні протеїнів, аліментарна нестача протеїну, гепатотоксичність, мітохондрії.

\section{АКТИВНОСТЬ МИТОХОНДРИАЛЬНЫХ ЭНЗИМОВ КАТАБОЛИЗМА ЭНДОГЕННЫХ АЛЬДЕГИДОВ В УСЛОВИЯХ АЦЕТАМИНОФЕН- ИНДУЦИРОВАННОЙ ГЕПАТОТОКСИЧНОСТИ}

\section{О. Н. Волощук, Г. П. Копыльчук, Ю. И. Мишина}

Черновицкий национальный университет имени Юрия Федьковича,

Институт биологии, химии и биоресурсов; e-mail: o.voloschuk@chnu.edu.ua

В работе изучена активность альдегиддегидрогеназы (КФ 1.2.1.3), альдегидредуктазы (КФ 1.1.1.21), содержание ТБК-активных продуктов и карбонильных производных протеинов в митохондриальной фракции печени крыс в условиях ацетаминофениндуцированного гепатита и алиментарной депривации протеина. Установлено, что наиболее выраженное снижение активности исследуемых энзимов наблюдалось в митохондриальной фракции печени крыс с токсическим повреждением, которые содержались в условиях дефицита протеина в пищевом рационе. В то же время в митохондриях печени животных этой группы установлено накопление ТБК-активных продуктов и протеиновых карбонил-дериватов. Высказывается предположение, что накопление альдегидных продуктов окислительного повреждения липидов и протеинов на фоне снижения активности энзимов, обеспечивающих их катаболизм, может лежать в основе одного из механизмов митохондриальной дисфункции в условиях токсического повреждения печени при алиментарной депривации протеина.

К л ю че в ы е сл ова: альдегиддегидрогеназа, альдегидредуктаза, ТБК-активные продукты, карбонильные производные протеинов, алиментарная недостаточность протеина, гепатотоксичность, митохондрии.

\section{References}

1. Nunnari J, Suomalainen A. Mitochondria: in sickness and in health. Cell. 2012; 148(6): 11451159.

2. Voelker DR. Genetic and biochemical analysis of non-vesicular lipid traffic. Annu Rev Biochem. 2009; 78: 827-856.

3. De Stefani D, Raffaello A, Teardo E, Szabò I, Rizzuto R. A forty-kilodalton protein of the inner membrane is the mitochondrial calcium uniporter. Nature. 2011; 476(7360): 336-340.

4. Hamanaka RB, Chandel NS. Mitochondrial reactive oxygen species regulate cellular signaling and dictate biological outcomes. Trends Biochem Sci. 2010; 35(9): 505-513.

5. Cadenas E. Mitochondrial free radical production and cell signaling. Mol Aspects Med. 2004; 25(12): $17-26$.

6. Whaley-Connell A, McCullough PA, Sowers JR. The role of oxidative stress in the metabolic syndrome. Rev Cardiovasc Med. 2011; 12(1): 2129.

7. O'Brien PJ, Siraki AG, Shangari N. Aldehyde sources, metabolism, molecular toxicity mechanisms, and possible effects on human health. Crit Rev Toxicol. 2005; 35(7): 609-662.

8. Barski OA, Tipparaju SM, Bhatnagar A. The aldo-keto reductase superfamily and its role in drug metabolism and detoxification. Drug Metab Rev. 2008; 40(4): 553-624.

9. Kopylchuk GP, Voloshchuk OM. Peculiarities of the free radical processes in rat liver mitochondria under toxic hepatitis on the background of alimentary protein deficiency. Ukr Biochem J. 2016; 88(2): 66-72.

10. Voloshchuk ON, Kopylchuk GP. The ratio of ubiquinon redox forms in the liver mitochondria under toxic hepatitis induced on the background of alimentary protein deficiency. Probl Nutr. 2015; 84(5): 82-87. (In Russian).

11. Kuvandik G, Duru M, Nacar A, Yonden Z, Helvaci R, Koc A, Kozlu T, Kaya H, Sogüt S. Effects of erdosteine on acetaminophen-induced hepatotoxicity in rats. Toxicol Pathol. 2008; 36(5): 714-719.

12. Kislova OV, Vinogradova EG, Pkhakadze GA. Comparative characteristics of membrane forms 
of aldehyde dehydrogenase. Ukr Biokhim Zhurn. 1995; 67(6): 38-45. (In Russian).

13. Fomina EV, Davydov VV. Aldehyde reductase activity in the liver of rats of various age at immobilization stress. Problemy Staren Dolgolet. 2004; 13(4): 510-516. (In Russian).

14. Rodrigues T, de França LP, Kawai C, de Faria PA, Mugnol KC, Braga FM, Tersariol IL, Smaili SS, Nantes IL. Protective role of mitochondrial unsaturated lipids on the preservation of the apoptotic ability of cytochrome $\mathrm{C}$ exposed to singlet oxygen. J Biol Chem. 2007; 282(35): 25577-25587.

15. Parihar MS, Pandit MK. Free radical induced increase in protein carbonyl is attenuated by low dose of adenosine in hippocampus and mid brain: implication in neurodegenerative disorders. Gen Physiol Biophys. 2003; 22(1): 29-39.

16. Lowry OH, Rosebrough NJ, Farr AL, Randall RJ. Protein measurement with the Folin phenol reagent. J Biol Chem. 1951; 193(1): 265-275.

17. Marchitti SA, Brocker C, Stagos D, Vasiliou V. Non-P450 aldehyde oxidizing enzymes: the aldehyde dehydrogenase superfamily. Expert Opin Drug Metab Toxicol. 2008; 4(6): 697-720.
18. Andringa KK, Bajt ML, Jaeschke H, Bailey SM. Mitochondrial protein thiol modifications in acetaminophen hepatotoxicity: effect on HMGCoA synthase. Toxicol Lett. 2008; 177(3): 188197.

19. Ayala A, Muñoz MF, Argüelles S. Lipid peroxidation: production, metabolism, and signaling mechanisms of malondialdehyde and 4-hydroxy-2-nonenal. Oxid Med Cell Longev. 2014; 2014: 360438.

20. Krysiuk IP, Knaub AJ, Shandrenko SG. Comparison of bioactive aldehydes modifying action on human albumin. Ukr Biochem J. 2014; 86(2): 68-78. (In Ukrainian).

21. Singh S, Brocker C, Koppaka V, Chen Y, Jackson BC, Matsumoto A, Thompson DC, Vasiliou V. Aldehyde dehydrogenases in cellular responses to oxidative/electrophilic stress. Free Radic Biol Med. 2013; 56: 89-101.

22. Kurahashi T, Kwon M, Homma T, Saito Y, Lee J, Takahashi M, Yamada K, Miyata S, Fujii J. Reductive detoxification of acrolein as a potential role for aldehyde reductase (AKR1A) in mammals. Biochem Biophys Res Commun. 2014; 452(1): 136-141.

Received 01.12.2017 